\title{
Human Exposure to Glyphosate and Methods of Detection: A Review
}

\author{
Sunisa CHAIKLIENG* and Kodchakorn UENGCHUEN
}

Department of Environmental Health, Occupational Health and Safety, Faculty of Public Health, Khon Kaen University, Khon Kaen 40002, Thailand

("Corresponding author's e-mail: csunis@kku.ac.th)

Received: 22 July 2019, Revised: 4 December 2019, Accepted: 11 January 2020

\begin{abstract}
Glyphosate is a broad-spectrum herbicide used extensively worldwide. The carcinogenic potential of glyphosate has been debated. This review aimed to describe human exposure, report environmental air concentrations in relation to occupational exposure, and identify the methods used to analyze glyphosate or AMPA concentrations. We searched, Google Scholar, Science Direct and PubMed for relevant papers in Thai or English, published from 2004 to 2017. Thus, 16 studies were identified. The results show that glyphosate and aminomethylphosphonic acid (AMPA) are markers of both internal and external exposure dose. Glyphosate is generally detected at concentrations comparable to or higher than AMPA. Human exposure has been assessed with measured levels of glyphosate ranging from 0.02 to $233 \mu \mathrm{g} / \mathrm{L}$ and a range of AMPA of 0.15 to $2.63 \mu \mathrm{g} / \mathrm{L}$ in human urine. The highest concentrations of glyphosate and AMPA found in blood were $171.1 \times 10^{3}$ and $2,600 \mu \mathrm{g} / \mathrm{L}$, respectively, from acute poisonings and intentional self-harm. Environmental air concentrations of glyphosate ranged from less than 0.01 to 46.80 $\mu \mathrm{g} / \mathrm{m}^{3}$ in the working field areas. Four methods used to analyze glyphosate and AMPA were identified: ELISA, HPLC-fluorescence/MS, GC-MS, LC-MS. While these results indicate the level of human exposure to glyphosate, the resulting human health effects of exposure are still uncertain. Therefore, there is a need for more investigation into human health risk assessment and application of health surveillance programs, particularly among glyphosate applicators.
\end{abstract}

Keywords: Ambient air, Aminomethylphosphonic acid, AMPA, Exposure, Glyphosate

\section{Introduction}

Thailand imports large quantities of hazardous substances, and the average for yearly import between 2011 and 2017 is 198,317 tons at a cost of about 27,922 million Thai Baht per year [1]. Herbicides are classified as hazardous substances in agricultural activity and the highest import quantity presented in 2017 was 148,979 tons accounting to $75.12 \%$ of those hazardous substances in agriculture [1]. Glyphosate is one herbicide type that inhibits specific enzyme function affecting a reduce of 3 aromatic amino acids, phenylalanine, tyrosine and tryptophan. These enzymes are necessary for the growth of plants. Glyphosate is a broad-spectrum herbicide used extensively worldwide.

Glyphosate's observed toxicity in humans is rather low but there were acute intoxications among patients exposed to glyphosate and got treatment at Changhau Christian hospital in Taiwan [2]. Among these 93 cases, the 1 st group of 13 patients experienced asymptomatic after dermal contact with spray and mild oral or nasal discomfort from accidental inhalation or ingestion. Another group of 80 patients with intentional ingestion of high doses reported to have experienced sore throat, dysphagia, gastrointestinal hemorrhage, toxicities in liver, kidney, lung, blood vessel and nervous system. In the latter group, 7 out of 80 patients died from hypotension and pulmonary edema. Moreover, there was a report of pneumonitis in an agriculturist exposed to glyphosate [2]. For chronic effect, the use of glyphosate toxicity to promote tumor initiator, 7, 12-dimethylbenz [a] anthracene (DMBA)-initiated mouse skin cells leading to tumor 
http://wjst.wu.ac.th

has been studied [3]. The carcinogenic potential of glyphosate has been debated. In 2015, the World Health Organization's International Agency for Research on Cancer (IARC) classified glyphosate as a Group 2A substance, i.e., probably carcinogenic to humans. The US. Environmental Protection Agency concluded in 2017 that glyphosate is not likely to be carcinogenic to humans, and the European Food Safety Authority maintains a similar stance. Bayer, which acquired Monsanto in 2018, states that glyphosate is a safe and efficient weed control tool.

One method of risk assessment for chemical exposures is the use of internal dose as a biomarker of exposure, whether of the parent compound or of its metabolite. Such metabolites can be detected from human biological fluid specimens such as blood, milk and urine [4]. To date, there is no occupational safety threshold standard, and human health risk assessment of glyphosate exposure from both internal and exposure dose assessment has not been much explored. As a result, this literature review aimed to assess the available biomarkers and concentrations of glyphosate in human exposure, and methods of detection to support data collection in further research studies or setting up of a recommended occupational limit of exposure.

\section{Materials and methods}

The literature review of relevant human studies from both domestic and international literature revealed 16 studies that met the 0 as follows:

1) A study of biomarkers and concentrations of glyphosate in humans, conducted either in Thailand or elsewhere.

2) Reported in a Thai or international research publication between 2004 - 2017.

The searching research was done by specified criteria as follows:

The search was performed using the terms for "glyphosate" ("glyphosate" OR "1071-83-6"OR "roundup" OR "N-(Phosphonomethyl) glycine”) OR ((“AMPA”) OR "Aminomethylphosphonic acid”) AND ("exposure" OR "metabolite" OR "concentration") AND ("human"). Keywords were presented in both Thai and English.

Searches were made from the following electronic databases : Google Scholar, ScienceDirect and PubMed.

Data analysis was done using descriptive statistics: minimum, maximum, mean and standard deviation (SD)

\section{Results and discussion}

Searching using the keywords retrieved 1,040 publications, from which 937 articles were subsequently excluded because no full text was available. 103 articles were found with keywords and full text available. Further restriction was employed to studies that reported complete data on analysis of biomarker and concentration levels. Finally, only 16 articles relating to human study were studied. The results of the review are divided into 3 issues for presentation; 1) internal dose of glyphosate exposure in human sample, 2) glyphosate and AMPA concentrations in ambient air monitoring of human exposure, and 3 ) additional information of analytical techniques for glyphosate and AMPA.

\section{Internal dose of glyphosate exposure in human sample}

There were finally 9 studies mentioning internal dose of exposure to glyphosate in concentration measurement from human urine samples between 2004 and 2017. In South Carolina and Minnesota, the maximum value of glyphosate concentrations in the urine of farmers, spouses and children were reported at $233 \mu \mathrm{g} / \mathrm{L}(233 \mathrm{ppb}), 3 \mu \mathrm{g} / \mathrm{L}$ (3 ppb) and $29 \mu \mathrm{g} / \mathrm{L}$ (29 ppb), respectively [5]. Moreover, farmers who did not wear gloves while mixing and loading herbicide were found to have glyphosate concentrations approximately 5 times higher than those wearing gloves [5]. The conclusion is that a decrease of glyphosate concentration in urine was partly due to protection by personal protective equipment (PPE). Children also had detectable glyphosate exposure while helping their fathers in herbicide mixing, loading, 
http://wjst.wu.ac.th

or application. The highest estimated systemic dose from the study was $0.004 \mathrm{mg} / \mathrm{kg} / \mathrm{day}$ [5] whereas the US. Environmental Protection Agency (EPA) reference dose for glyphosate daily intake was 1.75 $\mathrm{mg} / \mathrm{kg} /$ day [6]. Although the systemic dose was lower than the US, the EPA reference suggests that farmers should wear PPE whilst undertaking herbicide application. In Iowa, participants from farming families were detected to have a higher glyphosate concentration $(15.67 \mu \mathrm{g} / \mathrm{L})$ than those from nonfarmer families $(6.60 \mu \mathrm{g} / \mathrm{L})$. There was no significant difference between farm children and non-farm children [7]. A previous study showed that among farmers who had sprayed glyphosate, the parent compound detected in urine showed a maximum of $4.35,0.95$, and $1.90 \mu \mathrm{g} / \mathrm{L}$ on day 0 , day 1 and day 2 , respectively. Glyphosate (averaged $2 \mu \mathrm{g} / \mathrm{L}$ ) was also found in 1 of 3 farm children, but was not detectable in farm mothers' urine [8]. This study also discussed how unsuitable PPE and an individual's behavior would lead to higher exposure of glyphosate. This is evident when having an open window of the tractor's booth while spraying (even though a mask and gloves were worn) and not taking a shower after spraying [8].

From the farmers'family reviews, the highest glyphosate mean concentration reported was 88.33 $\mu \mathrm{g} / \mathrm{L}$. In Denmark, detectable glyphosate concentration in children ranged from 0.85 to $3.31 \mu \mathrm{g} / \mathrm{L}$ [9], but in Iowa, USA, no difference was found between farm and non-farm children's exposure to glyphosate, with maxima of $5.67 \mu \mathrm{g} / \mathrm{L}(0.33 \mathrm{mg} / \mathrm{kg} /$ day $)$ and $5.76 \mu \mathrm{g} / \mathrm{L}(0.34 \mathrm{mg} / \mathrm{kg} /$ day $)$, respectively [10]. There were 2 studies that detected glyphosate in mothers and lactating women with means of $1.28 \mu \mathrm{g} / \mathrm{L}(0.49$ $3.22 \mu \mathrm{g} / \mathrm{L}$ ) [9] and $0.28 \mu \mathrm{g} / \mathrm{L}$ [11], respectively. In addition, a previous study detected glyphosate in European adults from 18 countries with a maximum of $1.82 \mu \mathrm{g} / \mathrm{L}$ in urine [12]. Later, the German researchers found glyphosate residues ranging from 0.1 to $71.3 \mu \mathrm{g} / \mathrm{L}$ in urine samples of healthy and chronically diseased humans [13]. In 2017, a retrospective study (between 2001 to 2015) in the northeastern Germany found maxima of glyphosate concentration of 1.78 and $2.80 \mu \mathrm{g} / \mathrm{L}$ in German males and females, respectively [14]. A study in Thailand found glyphosate residue as high as $13.7 \mu \mathrm{g} / \mathrm{L}$ in urine of the Northern farmers collected in the morning post-exposure [15] as shown in Table 1.

Table 1 Glyphosate concentration in human urine from the studies between 2004 and 2017.

\begin{tabular}{lll}
\hline Population & Country reference & \multicolumn{1}{c}{ Concentration } \\
\hline Farmers' family & US. South Carolina and & Maximum: \\
& US. Minnesota [5] & Spouses $=3 \mu \mathrm{g} / \mathrm{L}$, Children $=29 \mu \mathrm{g} / \mathrm{L}$, \\
& Farmer $=233 \mu \mathrm{g} / \mathrm{L}$
\end{tabular}




\begin{tabular}{lll}
\hline Population & Country reference & \multicolumn{1}{c}{ Concentration } \\
\hline German adults & Germany $[13]$ & Range $=0.1-71.3 \mu \mathrm{g} / \mathrm{L}$ \\
German adults & Germany $[14]$ & $\begin{array}{l}\text { Maximum: Males }=1.78 \mu \mathrm{g} / \mathrm{L}, \text { Females }=2.80 \\
\mu \mathrm{g} / \mathrm{L}(\mathrm{LOD}=0.1 \mu \mathrm{g} / \mathrm{L})\end{array}$ \\
Farmers & Thailand $[15]$ & Mean $($ Northern farmers $)=13.7 \mu \mathrm{g} / \mathrm{L}$ \\
\hline
\end{tabular}

Generally, urinary glyphosate and AMPA levels have tended to be higher in males than females but sex-related differences in physiological determinants of glyphosate and AMPA in urine cannot be elucidated [14]. There were 3 studies analyzing AMPA that reported the major breakdown product of glyphosate. It was detected in the urine of male and female German adults at maximum concentrations of $1.54 \mu \mathrm{g} / \mathrm{L}$ and $1.88 \mu \mathrm{g} / \mathrm{L}$, respectively [14]. The highest AMPA detection was $2.63 \mu \mathrm{g} / \mathrm{L}$ in European adults [12]. A study of AMPA metabolite in lactating women's urine revealed a mean of $0.30 \mu \mathrm{g} / \mathrm{L}$ [11]. The findings in this literature review showed that glyphosate and AMPA in urine ranged from $<0.15$ to $233 \mu \mathrm{g} / \mathrm{L}$ and $<0.15$ to $2.63 \mu \mathrm{g} / \mathrm{L}$, respectively (Table 2). In addition, this review showed a range of 3 to $233 \mu \mathrm{g} / \mathrm{L}$ among farm workers and their family.

Table 2 AMPA detection in human urine sample from the studies between 2004 and 2017.

\begin{tabular}{|c|c|c|}
\hline Population & Country reference & Concentration \\
\hline European adults & European countries [12] & Range $=<0.15-2.63 \mu \mathrm{g} / \mathrm{L}$ \\
\hline German adults & Germany [14] & $\begin{array}{l}\text { Maximum } \\
\text { Males }=1.54 \mu \mathrm{g} / \mathrm{L}, \text { Females }=1.88 \mu \mathrm{g} / \mathrm{L}\end{array}$ \\
\hline Lactating women & $\begin{array}{l}\text { US. Moscow, Idaho and Pullman, } \\
\text { Washington [11] }\end{array}$ & Mean \pm S.D. $=0.30 \pm 0.33 \mu \mathrm{g} / \mathrm{L}$ \\
\hline
\end{tabular}

Apart from urine, glyphosate concentrations have also been measured in human blood and milk. There were 2 studies reporting glyphosate and AMPA concentrations in human blood. One found a level of mean glyphosate of $73.6 \mu \mathrm{g} / \mathrm{L}$ (S.D. $=28.2$ ) in blood of Canadian women, but AMPA was not found [16]. In another study conducted in Korea, glyphosate was detected at range of $1 \times 10^{3}-171.1 \times 10^{3} \mu \mathrm{g} / \mathrm{L}$ in the blood of female patients (one in human milk) admitted to the emergency room at a university hospital in Korea after glyphosate was self-administered in suicide attempts or by accident. The study illustrated a correlation between the concentration of glyphosate and the clinical symptoms [17]. There was one study in milk samples of lactating women that could not detect either glyphosate or AMPA (LOD and LOQ of 1 and $10 \mu \mathrm{g} / \mathrm{L}$ ) [11] as shown in Table 3. When considering the sensitivity of the biomarkers, glyphosate presented in higher concentration than AMPA. For the elimination half-life of glyphosate indicates that it can be excreted from human body within $3.1 \mathrm{~h}$ after exposure [9]. However, the elimination half-life of glyphosate in the blood was $9.99 \mathrm{~h}$ after intravascular injection, $48.8 \mathrm{~h}$ after oral admin, while AMPA needs $15.08 \mathrm{~h}$ to complete excretion after glyphosate parent compound ingestion [18]. This indicates that AMPA has longer half-life than glyphosate. 
http://wjst.wu.ac.th

Table 3 Glyphosate concentration in blood or milk sample from the studies between 2004 - 2017.

\begin{tabular}{|c|c|c|c|c|}
\hline Biomarker & Country & Population & Specimen & Concentration \\
\hline \multirow[t]{3}{*}{ Glyphosate } & Canada & Women & Blood & Mean \pm S.D. $=73.6 \pm 28.2 \mu \mathrm{g} / \mathrm{L}[16]$ \\
\hline & $\begin{array}{l}\text { US. Moscow, Idaho } \\
\text { and Pullman, } \\
\text { Washington }\end{array}$ & & Milk & $\begin{array}{l}\text { Not detectable } \\
(\mathrm{LOD}=1 \mu \mathrm{g} / \mathrm{L}, \mathrm{LOQ}=10 \mu \mathrm{g} / \mathrm{L})[11]\end{array}$ \\
\hline & Korea & Patients & Blood & Range $=1 \times 10^{3}-171.1 \times 10^{3} \mu \mathrm{g} / \mathrm{L}[17]$ \\
\hline \multirow[t]{3}{*}{ AMPA } & Canada & Women & Blood & Not detectable $(\mathrm{LOD}=10 \mu \mathrm{g} / \mathrm{L})[16]$ \\
\hline & $\begin{array}{l}\text { US. Moscow, Idaho } \\
\text { and Pullman, } \\
\text { Washington }\end{array}$ & & Milk & $\begin{array}{l}\text { Not detectable } \\
(\mathrm{LOD}=1 \mu \mathrm{g} / \mathrm{L}, \text { LOQ } 10 \mu \mathrm{g} / \mathrm{L})[11]\end{array}$ \\
\hline & Korea & Patients & Blood & Range $=200-2,600 \mu \mathrm{g} / \mathrm{L}[17]$ \\
\hline
\end{tabular}

Glyphosate and AMPA concentrations in ambient air to which human are exposed

Glyphosate and AMPA concentrations have been detected from environmental monitoring. Three studies reported measuring external exposure through ambient air media. In Malaysia, glyphosate was measured in the ambient air of operators' breathing zone by active and passive sampling. In active sampling during the 25 min spray application, the highest glyphosate exposure was $42.96 \mu \mathrm{g} / \mathrm{m}^{3}$ [19]. In passive sampling, the average glyphosate concentrations, $2.49 \pm 1.12 \mathrm{ng} / \mathrm{cm}^{2}$, were detected $0-4 \mathrm{~h}$ postspray. A significant finding is that the duration of herbicide application was related to the measured glyphosate concentration. One study reported that glyphosate concentration less than $1.25 \mu \mathrm{g} / \mathrm{m}^{3} \mathrm{was}$ detected during spraying at midweek compared with the maximum value of $15.7 \mu \mathrm{g} / \mathrm{m}^{3}$ which was measurable at the end of spraying week among forest worker spraying's breathing zone [20]. In Bermuda, glyphosate was detectable in ambient air, and exposures (13.3 to $\left.33.7 \mu \mathrm{g} / \mathrm{m}^{3}\right)$ inside the cab of the spraying vehicle were lower than at the rear of the vehicle (13.3 to $46.8 \mu \mathrm{g} / \mathrm{m}^{3}$ ) [20]. This study found that, due to glyphosate's very low vapor pressure, the airborne exposure route would be via water droplets containing glyphosate in a water mist that remains in the air before falling to the ground [21]. This liturature could recommend for the critical group (i.e. farmers and knapsack sprayers who were herbicide applicators) to work in humid weather in order to decrease glyphosate exposure via the inhalation route. The 3rd study was in the USA and found glyphosate and AMPA concentrations in the atmosphere in the range of $<0.01-9.10$ and $<0.01-0.97 \mu \mathrm{g} / \mathrm{m}^{3}$, respectively [22]. This showed concentrations of AMPA were lower than those of glyphosate (Table 4). This is to be expected during spraying as AMPA is a breakdown product of glyphosate. A review of occupational exposure to glyphosate showed that the average urinary levels of workers varied from 0.26 to $73.5 \mu \mathrm{g} / \mathrm{L}$. The maximum was higher than previous range from environment exposure shown the urinary levels ranged from 0.16 to $7.6 \mu \mathrm{g} / \mathrm{L}$ [23]. The glyphosate applicator can probably be exposed to glyphosate and AMPA through contaminated environmental sources. The previous review also found that the highest concentration of glyphosate and AMPA in ambient air of the working area were $46.8 \mu \mathrm{g} / \mathrm{m}^{3}$ and $0.97 \mu \mathrm{g} / \mathrm{m}^{3}$, respectively [23].

Furthermore, glyphosate and AMPA can be detected in other media; in Argentina, glyphosate and AMPA concentrations were detected in soils in the ranges of 35 to $1,502 \mu \mathrm{g} \mathrm{kg}^{-1}$ and 299 to $2,256 \mu \mathrm{g} \mathrm{kg}^{-1}$, respectively [24]. Glyphosate and AMPA concentrations in soils were not dependent on application day, although the highest glyphosate concentration in the atmosphere was found during application days [19]. Moreover, glyphosate in sediment was better correlated with the total number of applications than with the last spraying event dose and an increment of $1 \mathrm{mg}$ glyphosate/kg soil for every 5 spraying events was estimated [25]. In USA, glyphosate on a raining day was detected also in rain water ranging from $<0.10$ to $2.5 \mu \mathrm{g} / \mathrm{L}$ (as well as both glyphosate and AMPA being detected in ambient air) [21]. One study found 
http://wjst.wu.ac.th

glyphosate and AMPA in surfacewater as the maximum concentrations of 1.8 and $1.9 \mu \mathrm{g} / \mathrm{L}$, respectively, but with no detectable concentrations in groundwater [25]. Hence, farmers may be exposed to glyphosate as well as its metabolite (AMPA) through environment-contact routes with inhaled air, soils and water in the working setting (Table 4).

Table 4 Concentrations of glyphosate and AMPA from ambient air sample.

\begin{tabular}{clll}
\hline Marker & \multicolumn{1}{c}{ Country/ state } & \multicolumn{1}{c}{ Population or area } & \multicolumn{1}{c}{ Concentration } \\
\hline Glyphosate & Malaysia & Farmer field [19] & $\begin{array}{l}\text { Maximum in breathing zone }=42.96 \\
\mu \mathrm{g} / \mathrm{m}^{3}(\text { S.D. }=7.96)\end{array}$ \\
& Bermuda & Road side spraying [20] & Range $=13.3-46.8 \mu \mathrm{g} / \mathrm{m}^{3}$ \\
& US. Mississippi, Iowa & Agricultural areas [21] & Range $=<0.01-9.10 \mu \mathrm{g} / \mathrm{m}^{3}$ \\
\multirow{2}{*}{ AMPA } & US. Mississippi, Iowa & Agricultural areas [21] & Range $=<0.01-0.97 \mu \mathrm{g} / \mathrm{m}^{3}$ \\
\hline
\end{tabular}

\section{Analytical techniques of glyphosate detection from human exposure}

Fourteen studies referred to techniques of analysis of glyphosate exposure in humans. The main techniques were enzyme-linked immunosorbent assay (ELISA), high performance liquid chromatography (HPLC-Fluorescence), gas chromatograph-mass spectrometry (GC-MS), and liquid chromatography-mass spectrometry (LC-MS). Those techniques were used for both glyphosate and AMPA concentrations analysis. There were three predominant techniques ELISA [9], HPLC-MS or HPLC-fluorescence [19-23] and GC-MS $[12,13,16]$. The previous studies found that analysis of glyphosate concentration by ELISA technique and a repeat test using GC-MS yielded a good correlation coefficient between the 2 techniques for human urine or other specimens [25,26]. In urine samples, glyphosate could be detected at a lower concentration limits of $0.075 \mu \mathrm{g} / \mathrm{L}$ by ELISA [9], minimum of $0.02 \mu \mathrm{g} / \mathrm{L}$ [11] and maximum of $4.35 \mu \mathrm{g} / \mathrm{L}$ by LC-MS [8] and $0.15 \mu \mathrm{g} / \mathrm{L}$ by GC-MS [13]. AMPA can be detected in urine at a lower concentration limit of $0.03 \mu \mathrm{g} / \mathrm{L}$ by LC-MS method [10] and $0.15 \mu \mathrm{g} / \mathrm{L}$ by GC-MS/MS [14]. In blood samples, glyphosate can be detected at a minimum of $50 \mu \mathrm{g} / \mathrm{L}$ (LOD) by LC-MS/MS [17] or $10 \mu \mathrm{g} / \mathrm{L}$ by GC-MS [16]. Techniques used to analyze internal exposure measurement as biomarkers were rather more varied than techniques that analyzed glyphosate in ambient air. All three studies about ambient air measurement or personal sampling used mainly HPLC techniques as they are simple but have sufficient sensitivity (Table 5). 
http://wjst.wu.ac.th

Table 5 Methods for glyphosate detection on human exposure.

\begin{tabular}{|c|c|c|}
\hline Technique & Sample & Marker and concentration \\
\hline \multirow[t]{2}{*}{ ELISA } & Urine [9] & $\begin{array}{l}\text { Glyphosate: } \\
\text { Mean }=1.08 \mu \mathrm{g} / \mathrm{L}, \mathrm{LOD}=0.075 \mu \mathrm{g} / \mathrm{L}\end{array}$ \\
\hline & Urine [13] & Glyphosate: $9 \mu \mathrm{g} / \mathrm{L}(0.1-71.3 \mu \mathrm{g} / \mathrm{L})$ \\
\hline \multirow{6}{*}{$\begin{array}{l}\text { enzyme-linked } \\
\text { immunosorbent assay } \\
\text { (ELISA) }\end{array}$} & Urine [10] & Glyphosate: Maximum \\
\hline & & Farm children $=5.67 \mu \mathrm{g} / \mathrm{L}$ \\
\hline & & Non-farm children $=5.76 \mu \mathrm{g} / \mathrm{L}$ \\
\hline & Urine [7] & Glyphosate: Mean \\
\hline & & Farm family members $=15.67 \mu \mathrm{g} / \mathrm{L}$ \\
\hline & & Non-farm family members $=6.6 \mu \mathrm{g} / \mathrm{L}$ \\
\hline \multirow{2}{*}{$\begin{array}{l}\text { Liquid chromatography- } \\
\text { tandem mass spectrometry } \\
\text { (LC-MS) }\end{array}$} & Urine [11] & $\begin{array}{l}\text { Glyphosate: Mean } \pm \text { S.D. }=0.28 \pm 0.38 \mu \mathrm{g} / \mathrm{L} \text {, } \\
\mathrm{LOD}=0.02 \mu \mathrm{g} / \mathrm{L}\end{array}$ \\
\hline & & $\begin{array}{l}\text { AMPA: Mean } \pm \text { S.D. }=0.30 \pm 0.33 \mu \mathrm{g} / \mathrm{L} \\
\mathrm{LOD}=0.03 \mu \mathrm{g} / \mathrm{L}\end{array}$ \\
\hline Liquid chromatography- & Urine $[8]$ & Glyphosate: \\
\hline $\begin{array}{l}\text { linear ion trap mass } \\
\text { spectrometry }\end{array}$ & & Maximum $=4.35 \mu \mathrm{g} / \mathrm{L}, \mathrm{LOD}=1 \mu \mathrm{g} / \mathrm{L}$ \\
\hline Liquid chromatography & Blood [17] & Glyphosate range $=1,000-171.1 \times 10^{3} \mu \mathrm{g} / \mathrm{L}$, \\
\hline coupled to tandem mass & & AMPA range $=200-2,600 \mu \mathrm{g} / \mathrm{L}$ \\
\hline spectrometry (LC-MS/MS) & & $\mathrm{LOD}=50 \mu \mathrm{g} / \mathrm{L}, \mathrm{LOQ}=100 \mu \mathrm{g} / \mathrm{L}$ \\
\hline LC-MS & Milk [11] & $\begin{array}{l}\text { Glyphosate \& AMPA }=\text { Not detectable } \\
(\mathrm{LOD}=1 \mu \mathrm{g} / \mathrm{L}, \mathrm{LOQ}=10 \mu \mathrm{g} / \mathrm{L})\end{array}$ \\
\hline \multirow[t]{2}{*}{ GC-MS } & Blood [16] & Glyphosate: Range $=<10-93.6 \mu \mathrm{g} / \mathrm{L} \&$ \\
\hline & & AMPA $=$ Not detectable $(\mathrm{LOD}=10 \mu \mathrm{g} / \mathrm{L})$ \\
\hline GC-MS/MS & Urine $[13]$ & Glyphosate: Range $=5.4 \mu \mathrm{g} / \mathrm{L}(0.1-40 \mu \mathrm{g} / \mathrm{L})$ \\
\hline \multirow[t]{2}{*}{ GC-MS/MS } & Urine [12] & Glyphosate: Maximum $=1.82 \mu \mathrm{g} / \mathrm{L} \&$ \\
\hline & & AMPA $=2.63 \mu \mathrm{g} / \mathrm{L} ; \mathrm{LOD}=0.15 \mu \mathrm{g} / \mathrm{L}$ \\
\hline HPLC-FIuorescence & Ambient air [19] & 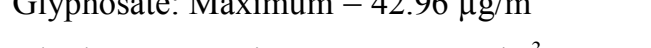 \\
\hline HPLC/MS & Ambient air [20] & Glyphosate: Maximum $=46.80 \mu \mathrm{g} / \mathrm{m}^{3}$ \\
\hline HPLC/MS & Ambient air [21] & Glyphosate: Maximum $=9.10 \mu \mathrm{g} / \mathrm{m}^{3}$ \\
\hline HPLC/MS & Ambient air [21] & AMPA: Maximum $=0.97 \mu \mathrm{g} / \mathrm{m}^{3}$ \\
\hline
\end{tabular}

\section{Conclusions}

From the 16 studies reviewed, the biomarkers of internal dose exposure are glyphosate and AMPA, which could be detected in urine and blood or milk. Glyphosate is almost always detected at concentrations higher comparable to or than AMPA. Glyphosate detection in urine among farmers or family members was in the range of $3-233 \mu \mathrm{g} / \mathrm{L}$. Considering overall farm or non-farm, detected range of glyphosate concentrations in urine was $0.02-233 \mu \mathrm{g} / \mathrm{L}$ and AMPA was detected in the range of 0.15 $2.63 \mu \mathrm{g} / \mathrm{L}$. The highest concentration of glyphosate and AMPA detected in blood was $171.1 \times 10^{3} \mu \mathrm{g} / \mathrm{L}$ and $2,600 \mu \mathrm{g} / \mathrm{L}$, respectively. By ambient air monitoring, glyphosate was detected among farmers' exposure in the range of less than $0.01-46.8 \mu \mathrm{g} / \mathrm{m}^{3}$. There were four reported techniques, i.e. ELISA, HPLC fluorescence/MS, GC-MS and LC-MS, which were confirmed to detect glyphosate and AMPA concentration as internal or external dose of exposure. Although there was a review of occupational exposure to glyphosate by detection in human urine, studies of both direct exposures in working area and environmental contact are needed in order to assess the estimate health risk. While these results indicate the level of human exposure to glyphosate, there is currently no standard occupational limit for human 
http://wjst.wu.ac.th

exposure and the resulting human health effects of exposure are still uncertain. Therefore, further studies should be concerned about exposure concentration among critical users involved in farming and human health risk assessment among glyphosate applicators. A health surveillance program among glyphosate applicators should be set up and promoted.

\section{Acknowledgements}

We are very grateful to Ms. Kate Jones, Toxicologist from HSE Science and Research Centre, UK and Chair of Scientific Committee in Occupational Toxicology of International Commission Occupational Health (SCOT-ICOH) for her valuable discussion and for the English language editing.

\section{References}

[1] Office of Agricultural Economics. Quantity and Value of Agriculture's Hazardous Substance Imported 2554 - 2560, Available at: http://oldweb.oae.go.th/economicdata/pesticides.html, accessed September 2018.

[2] Ramathibodi Poison Center. Poison \& Drug Information Bulletin, Available at: https://med.mahidol.ac.th/poisoncenter/th/bulletin/bul99/ v7n3/Herb, accessed September 2018.

[3] J George, S Prasad, Z Mahmood and Y Shukla. Studies on glyphosate-induced carcinogenicity in mouse skin: A proteomic approach. J. Proteomics. 2010; 73, 951-64.

[4] A Popoltap. Biomarkers for risk assessment of exposure from fungi's toxicity, Available at: http://thaimycotoxin.org/?p=316, accessed July 2018.

[5] FJ Acquavella, HB Alexander, SJ Mandel, C Gustin, B Baker, P Chapman and M Bleeke. Glyphosate biomonitoring for farmers and their families: Results from the farm family exposure study. Environ. Health. Perspect. 2004; 112, 321-6.

[6] US Environmental Protection Agency (EPA). Human-health Assessment Scoping Document in Support of Registration Review: Glyphosate. US. EPA Office of Prevention, Pesticides, and Toxic Substances, Office of Pesticide Programs, US. Government Printing Office, Washington, DC, 2009.

[7] BD Curwin, MJ Hein, WT Sanderson, C Striley, D Heederik, H Kromhout, SJ Reynolds and MC Alavanja. Urinary pesticide concentrations among children, mothers and fathers living in farm and non-farm households in Iowa. Ann. Occup. Hyg. 2007; 51, 53-65.

[8] R Mesnage, C Moesch, RLG Grand, G Lauthier, JSD Vendômois, S Gress and GE Sralini. Glyphosate exposure in a farmer's family. J. Environ. Protect. 2012; 3, 1001-3.

[9] LE Knudsen, PW Hansen, S Mizrak, HK Hansen, TA Mørck, F Nielsen, V Siersma and L Mathiesen. Biomonitoring of Danish school children and mothers including biomarkers of PBDE and glyphosate. Rev. Environ. Health 2017; 32, 279-90.

[10] BD Curwin, MJ Hein, WT Sanderson, C Striley, D Heederik, H Kromhout, SJ Reynolds and MC Alavanja. Pesticide dose estimates for children of Iowa farmers and non-farmers. Environ. Res. 2007; 105, 307-15.

[11] MK McGuire, MA McGuire, WJ Price, B Shafii, JM Carrothers, KA Lackey, DA Goldstein, PK Jensen and JL Vicini. Glyphosate and aminomethylphosphonic acid are not detectable in human milk. Am. J. Clin. Nutr. 2016; 103, 1285-90.

[12] HW Hoppe. Determination of Glyphosate Residues in Human Urine Samples from 18 European Countries. Report Glyphosate MLHB-2013-06-06, Germany, 2013, p. 1-13.

[13] M Krüger, P Schledorn, W Schrödl, HW Hoppe, W Lutz and AA Shehata. Detection of glyphosate residues in animals and humans. J. Environ. Anal. Toxicol. 2014; 4, 1-5.

[14] A Conrad, C Schröter-Kermani, HW Hoppe, M Rüther, S Pieper and M Kolossa-Gehring. Glyphosate in German adults - Time trend (2001 to 2015) of human exposure to a widely used herbicide. Int. J. Hyg. Environ. Health 2017; 220, 8-16.

[15] W Polyiem, S Hongsibsong, S Chantara, T Kerdnoi, V Patarasiriwong and T Prapamontol. Determination and assessment of glyphosate exposure among farmers from northern part of Thailand. J. Pharmacol. Toxicol. 2017; 12, 97-102. 
http://wjst.wu.ac.th

[16] A Aris and S Leblanc. Maternal and fetal exposure to pesticides associated to genetically modified foods in Eastern Townships of Quebec. Reprod. Toxicol. 2011; 31, 528-33.

[17] J Han, H Moon, Y Hong, S Yang, WJ Jeong, KS Lee and H Chung. Determination of glyphosate and its metabolite in emergency room in Korea. Forensic Sci. Int. 2016; 265, 41-6.

[18] A Anadón, MR Martínez-Larrañaga, MA Martínez, VJ Castellano, M Martínez, MT Martin, MJ Nozal and JL Bernal. Toxicokinetics of glyphosate and its metabolite aminomethyl phosphonic acid in rats. Toxicol. Lett. 2009; 190, 91-5.

[19] MdM Morshed, D Omar, RB Mohamad and SBA Wahed. Determination of glyphosate through passive and active sampling methods in a treated field atmosphere. Afr. J. Agric. Res. 2011; 6, 40108.

[20] A Jauhiainen, K Räsänen, R Sarantila, J Nuutinen and J Kangas. Occupational exposure of forest workers to glyphosate during brush saw spraying work. Am. Ind. Hyg. Assoc. J. 1991; 52, 61-4.

[21] GC Smith. Glyphosate Monitoring Study Evaluation of the Exposure Rsks from Glyphosate and Associated Degradation Products from Road-side Spraying for Weed Control. $1^{\text {st }}$ Ed, Government of Bermuda Ministry of the Environment, Bermuda, 2013, p. 1-31.

[22] FC Chang, M Simcik and P Capel. Occurrence and fate of the herbicide glyphosate and its degradate aminomethyl phosphonic acid in the atmosphere. Environ. Toxicol. Chem. 2011; 30, 548-55.

[23] C Gillezeau, MV Gerwen, RM Shaffer, I Rana, L Zhang, L Sheppard and E Taioli. The evidence of human exposure to glyphosate: A review. Environ. Health 2019; 18, 1-14.

[24] CV Aparicio, DE Geronimo, D Marino, J Primost, P Carriquiriborde and LJ Costa. Environmental fate of glyphosate and aminomethylphosphonic acid in surface waters and soil of agricultural basins. Chemosphere 2013; 93, 1866-73.

[25] EJ Primost, JGD Marino, CV Aparicio, LJ Costa and P Carriquiriborde. Glyphosate and AMPA, 'pseudo-persistent' pollutants under real-world agricultural management practices in the Mesopotamic Pampas agroecosystem. Environ. Pollut. 2017; 229, 771-9.

[26] M Krüger, W Schrödl, J Neuhaus and AA Shehata. Field investigations of glyphosate in urine of Danish dairy cows. J. Environ. Anal. Toxicol. 2013; 3, 1-7. 